\title{
CYTOGENETICS OF Pennisetum purpureum Schumack $x$ Pennisetum glaucum L. HYBRIDS AND THEIR PARENTS ${ }^{1}$
}

\author{
SANDRO BARBOSA ${ }^{2}$ \\ LISETE CHAMMA DAVIDE ${ }^{3}$ \\ ANTÔNIO VANDER PEREIRA ${ }^{4}$
}

\begin{abstract}
Cytogenetic studies were carried out on five accesses of interspecific hybrids of Pennisetum purpureum and Pennisetum glaucum and their parentals, which are part of the Forage Germplasm Bank of the "Centro Nacional de Pesquisa de Gado de Leite" of EMBRAPA, Brazil. The mitotic cytogenetic analysis, performed using stain by Schiff reactive, confirmed the chromosome number of $2 n=14,28$ and 21 for the accesses of $P$. glaucum, $P$. purpureum and their hybrids, respectively. For each access, descriptions of the chromosome complement and idiograms are presented which allowed to establish the karyotypic
\end{abstract}

relationships between the hybrids and their parentals. Based on the total chromosomal length data it was possible to establish the karyotype classification of the accesses concerning symmetry. While the karyotype of $P$. glaucum accesses was considered symmetric, hybrids presented asymmetric karyotypes. For $P$. purpureum, two accesses (BAGs 63 and 75) showed symmetric karyotype and three (BAGs 54, 65 and 91) were asymmetric. For the interspecific hybrids it was possible to infer the origin of some parental chromosomes based on the total chromosomal length measurements, satellite presence and chromosome morphology.

INDEX TERMS: Elephant grass, pearl millet, interspecific hybrids, cytogenetic, ideograms, chromosome.

\section{CITOGENÉTICA DE HÍBRIDOS ENTRE Pennisetum purpureum Schumack E Pennisetum glaucum L. E SEUS GENITORES}

\begin{abstract}
RESUMO - Foram realizados estudos citogenéticos em quinze acessos do Banco de Germoplasma Forrageiro, da Embrapa Gado de Leite, sendo cinco híbridos interespecíficos de Pennisetum purpureum e Pennisetum glaucum e seus genitores. As análises citogenéticas mitóticas realizadas mediante coloração com reativo de Schiff confirmaram o número cromossômico de $2 \mathrm{n}=14,28$ e 21 para os acessos de $P$. glaucum, $P$. purpureum e híbridos, respectivamente. Para cada um desses acessos, foram realizadas descrições do complemento cromossômico e idiogramas, as quais possibilitaram estabelecer relações cariotípicas entre os híbridos e seus genitores. Com base nos da-
\end{abstract}

dos de comprimento total do cromossomo, foi estabelecida a classificação do cariótipo dos acessos com relação à simetria. Os cariótipos dos acessos de $P$. glaucum foram considerados simétricos, ao passo que os híbridos apresentaram cariótipos assimétricos. Para $P$. purpureum, dois acessos (BAGs 63 e 75) mostraram cariótipos simétricos e três (BAGs 54, 65 e 91) assimétricos. Nos híbridos interespecíficos entre $P$. purpureum e $P$. glaucum, foi possível inferir a procedência de alguns cromossomos parentais com base nas medidas de comprimento total do cromossomo, presença de satélite e morfologia do cromossomo.

TERMOS PARA INDEXAÇÃO: Capim-elefante, milheto, híbrido interespecífico, citogenética, idiograma, cromossomo.

1. Parte da Dissertação apresentada ao Programa de Pós-graduação em Agronomia/Genética e Melhoramento de Plantas, para obtenção do título de Mestre.

2. Biólogo, Mestre, Departamento de Biologia, UNIVERSIDADE FEDERAL DE LAVRAS/UFLA, Caixa Postal 37, 37200-000, Lavras, MG, sandro@ufla.br.

3. Bióloga, Doutora, Professora Titular, Departamento de Biologia/UFLA, Icdavide@ufla.br.

4. Engenheiro Agrônomo, Doutor, Pesquisador, Embrapa - Gado de Leite, Rua Eugênio do Nascimento, 610, 36038330 - Juiz de Fora, MG. avanderp@cnpgl.embrapa.br 


\section{INTRODUCTION}

The Germplasm bank for forage plants at Embrapa Dairy Cattle, located in Coronel Pacheco MG, has one of the largest Pennisetum collections in Brazil, with 120 elephant grass and 50 pearl millet accessions. The germplasm is genetically constituted by clones, populations and $P$. purpureum improved cultivars, chromosome races (triploids and hexaploids) resulting from hybridization between $P$. purpureum $\mathrm{x} P$. glaucum, $P$. glaucum accessions and various other wild Pennisetum species.

Pennisetum purpureum Schumack $(2 \mathrm{n}=4 \mathrm{x}=28$ - A'A'BB genome) and pearl millet (Pennisetum glaucum (L.) R. BR.) ( $2 \mathrm{n}=2 \mathrm{x}=14$, AA genome) are directly related species presenting good genetic combining ability, producing low fertility or sterile interspecific hybrids that are, however, of great forage interest because they are better accepted by cattle than elephant grass itself (Jahuar, 1981; Shank \& Chynoweth Normally, 1993; Diz, 1994). The interspecific hybrid usually has greater similarity to the elephant grass type due to the larger genetic contribution (2/3 of the chromosomes) and dominance of the elephant grass $\mathrm{B}$ genome over the pearl millet A genome for the analyzed forage characteristics (Gonzalez \& Hanna, 1984.) These hybrids have 21 somatic chromosomes, which can be traced to each species by metaphase size and morphology. Pearl millet chromosomes are larger than those of elephant grass (Burton, 1942; Jahuar, 1981; Pantulu \& Rao, 1982; Jahuar \& Hanna, 1998). According to Jahuar (1981), its karyotype is symmetrical due to the presence of metacentric and submetacentric chromosomes and to the fact that the largest chromosome is 1.5 times the size of the smallest, and is, therefore, included in the la category of the asymmetry classification proposed by Stebbins (1958). The same author described the elephant grass karyotype as asymmetrical, consisting of metacentric, submetacentric and one acrocentric chromosomes and included it in the 2 b category (Stebbins, 1958).

Detailed cytogenetic studies on parents and hybrids obtained from interspecific crosses are of interest to locate chromosome markers useful to detect interaction among genomes and in genetic breeding programs.

The objective of this study was to cytogenetically characterize the parents of five crosses between elephant grass and pearl millet and investigate the hybrid nature of their progeny.

\section{MATERIAL AND METHODS}

Five supposed hybrids from the cross between elephant grass (Pennisetum purpureum Schum.) and pearl millet (Pennisetum glaucum (L.) R.Br) and their respective parents were assessed. Table 1 shows the genotypic materials used in this study belonging to the Forage Plant Germplasm Bank at Embrapa Dairy Cattle, located in Coronel Pacheco - MG. The elephant grass and pearl millet accessions used as parents were selected based on the allelic complementation and on expression of important forage traits. The crosses were performed artificially and five supposed F1 hybrids with best forage performance were selected for this study.

TABLE 1 - Identification of the P. purpureum (BAG), and Pennisetum glaucum (M) accessions and the supposed interspecific hybrids (CNPGL) from the Germplasm Bank at Embrapa Dairy Cattle, Coronel Pacheco - MG. UFLA Lavras, MG 2000.

\begin{tabular}{cccccc}
\hline $\begin{array}{c}\text { Registro do } \\
\text { acesso }\end{array}$ & $\begin{array}{c}\text { Denominação co- } \\
\text { mum }\end{array}$ & $\begin{array}{c}\text { Registro do } \\
\text { acesso }\end{array}$ & $\begin{array}{c}\text { Denominação } \\
\text { comum }\end{array}$ & $\begin{array}{c}\text { Registro } \\
\text { do acesso }\end{array}$ & $\begin{array}{c}\text { Denominação } \\
\text { comum }\end{array}$ \\
\hline BAG 54 & Capim Cana D’África & M 24 & ICMB 90111 & CNPGL94-F44-03 & BAG 63 x M36 \\
BAG 63 & Cuba 169 & M 35 & ICMP 89410 & CNPGL94-F49-06 & BAG 91 x M38 \\
BAG 65 & Roxo Botucatu & M 36 & AFPOP88 & CNPGL94-F52-02 & BAG 54 x M44 \\
BAG 75 & IJ 7136 & M 38 & AFPOP 90 & CNPGL94-F53-02 & BAG 65 x M35 \\
BAG 91 & Pasto Panamá & M 44 & Bulk 1 & CNPGL94-F60-01 & BAG 75 x M24 \\
\hline
\end{tabular}


The cytogenetic analyses were performed according to the procedures adapted by Techio (1998) for the Pennisetum species. The root cell cycles were synchronized by treatment with at $2.5 \mathrm{mM}$ for 14 hours, pre-treating with $25 \mathrm{mg} / \mathrm{l}$ solution and $300 \mathrm{mg} / \mathrm{l}$ (1:1) for $2 \mathrm{~h} 45 \mathrm{~m}$ followed by fixing in Carnoy solution for $24 \mathrm{~h}$ and enzymatic maceration in pectinase. The roots were stained with Schiff reagent and slides were prepared using the squashing technique.

The photomicrograph metaphases were digitalized and analyzed using the Jandel Sigma Scan ® Pro v. 2.20 software. The longest arm length (Bl), shortest arm length (Bc), total chromosome length $\mathrm{i}(\mathrm{Cti}=\mathrm{Bl}+\mathrm{Bc})$, the arm ratio $(\mathrm{RB}=\mathrm{Bl} / \mathrm{Bc})$, haploid set total length $(\mathrm{CTLH}=$ $\mathrm{Cti} / 2)$ and the relative length $(\mathrm{CR}=\mathrm{Cti} / \mathrm{CTLH} \times 100)$ were obtained. The chromosomes were morphologically classified according to the Levan et al. (1964) nomenclature.

The chromosomes were organized using the means of their arm ratio (RB) and relative length values (CR), numbered in decreasing size order from I to VII, I to XIV I to XXI, respectively, for pearl millet, elephant grass and the interspecific hybrids and represented in an ideogram.

An analysis of variance of the total complement length (CTLH) among accessions within the genotypes was performed. The accession means were compared by the Scott and Knott test (1974) at the 5\% level of significance.

\section{RESULTS AND DISCUSSION}

The somatic chromosome number for the five pearl millet, elephant grass and interspecific hybrid accessions was 14, 28 and 21, respectively (Figure 1), confirming the hybrid nature of the progeny studied (Burton, 1942, Pantulu, 1958; Burton \& Powell, 1968; Manara, 1973; Jahuar, 1981; Pantulu \& Rao, 1982; Techio 1998). Only the elephant grass BAGs 54 and 65 accessions among the genotypic materials assessed in this study had been described by Techio (1998) for chromosome number. In the present study, the chromosome complement of the three taxa was described in greater detail.
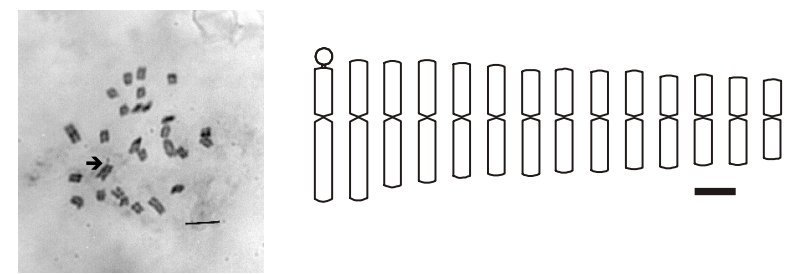

A
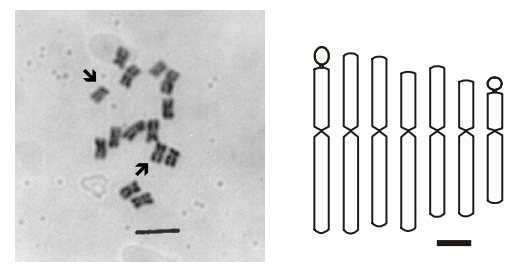

B
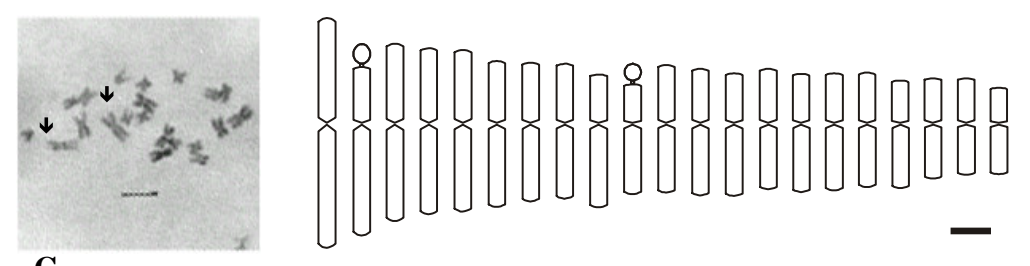

FIGURE 1 - Somatic metaphases and ideograms of A - Pennisetum purpureum $(2 \mathrm{n}=4 \mathrm{x}=28)$, B Pennisetum glaucum $(2 \mathrm{n}=2 \mathrm{x}=14), \mathrm{C}-$ interspecific hybrid $(2 \mathrm{n}=3 \mathrm{x}=21)$. The arrows indicate satellites and the bars in the photographs represent $5 \mu \mathrm{m}$.

Ciênc. agrotec., Lavras. V.27, n.1, p.26-35, jan./fev., 2003 
Elephant grass: The relative chromosome lengths of the BAGS 54, 65 and 91 accessions showed that the largest chromosome pair represented, on average, $10.4 \%$ of the haploid set length. Its length could reach twice the size of the last pair, whose relative length represented on average, $5.2 \%$ of the haploid set (Table 2). The ratio between the largest and smallest chromosomes did not reach the ratio of $2: 1$ in the BAGs 63 and 75 accessions. All the accessions presented metacentric chromosomes (Table 2). This fact associated to the 2:1 ratio in length between the largest and smallest pair in the accessions BAGs 54, 65 and 91 suggested that their karyotype should be included in the $\mathbf{2 b}$ category (Stebbins, 1958) classification of chromosome complement asymmetry. Accessions BAGs 63 and 75 showed symmetric karyotype of the 1a category due to their smaller than 2:1 chromosome arm ratio.

Satellites were observed on the short arm of one of the homologues of the first chromosome pair in four accessions (Table 2). In BAG 54, these structures were present on the two homologues of the pair. Techio (1998) had also registered the presence of satellites on two chromosomes in BAG 54. In BAG 63 , the $4^{\text {th }}$ pair also presented a satellite on one of the homologues.

The presence of these structures has been recorded as an important morphological characteristic in the chromosomes of some Pennisetum species. Pantulu \& Venkateswarlu (1968) observed in pachytene that the $1^{\text {st }}$ and $14^{\text {th }}$ chromosome pairs of the $P$. purpureum complement presented terminal satellites. Manara (1973) observed the presence of satellites on the short arm of one of the homologues of one or two chromosome pairs in eight elephant grass varieties.

Satellite presence is therefore evident on the largest pair of chromosomes of elephant grass where this structure appears to be more stable. A second chromosome of the complement may present a satellite, as is the case of chromosome IV of the BAG 63 accession studied in this research and of the $14^{\text {th }}$ pair, observed by Pantulu \& Venkateswarlu (1968).

According to Manara (1973), recording satellites on only one of the homologues of the chromosome pair could be explained by the simple loss of a segment of the arm that had the satellite or, possibly, by the occurrence of hybrid combinations where there was no satellite presence in one of the parent species. A further explanation may be errors in the classification of chromosome pairs because of minimal differences in their size and morphology. In this case, the use of the banding techniques could help chromosome pair identification.

Pearl Millet: Regarding the relative length, it was observed that the largest pair of chromosomes represented on average $17.1 \%$ of the haploid set length. Its size could reach 1.6 times that of the last pair, whose relative length represented, on average, $10.8 \%$ of the haploid set (Table 3).

The five pearl millet accessions studied presented metacentric and submetacentric chromosomes. In four of the accessions (M 24, M35, M36 and M44), chromosomes I, II, IV and VII were classified as metacentric and chromosomes III and VI as submetacentric. Chromosomes IV and VI of accession M 38 were classified as submetacentric and the others as metacentric (Table 3).

Studies on pearl millet chromosomes showed the occurrence of metacentric and submetacentric chromosomes and the largest pair would be approximately 1.5 times longer than the smallest (Avdulov, 1931; Burton \& Powell, 1968). Based on these data, Jahuar (1981) classified the pearl millet karyotype as symmetrical and considered it as the most representative karyotype of the 1a category in the Stebbins (1958) asymmetry classification.

From the obtained results, especially regarding the 1.6-fold difference in size between the largest and smallest chromosome (Table 3), the pearl millet accessions could be placed in the 1a Stebbins category (1958), as proposed by Jahuar (1981).

In the M35, M36, M38 and M44 accessions, the presence of satellites on the short arm of one of the homologues of the $1^{\text {st }}$ and $7^{\text {th }}$ pairs of chromosomes was ascertained. In the M24 accession, the satellite was observed on the short arm of one of the VII pair homologues. The presence of satellites on 1 or 2 pairs of chromosomes was reported in pearl millet by several authors (Pantulu (1958); Burton \& Powell, 1968; Pantulu \& Venkateswarlu (1968); Jahuar, 1981). Gill \& Gupta, quoted by Burton \& Powell (1968) located the satellite on the short arm of the largest chromosome of the complement. In all reports, the smallest chromosome pair had a satellite. 


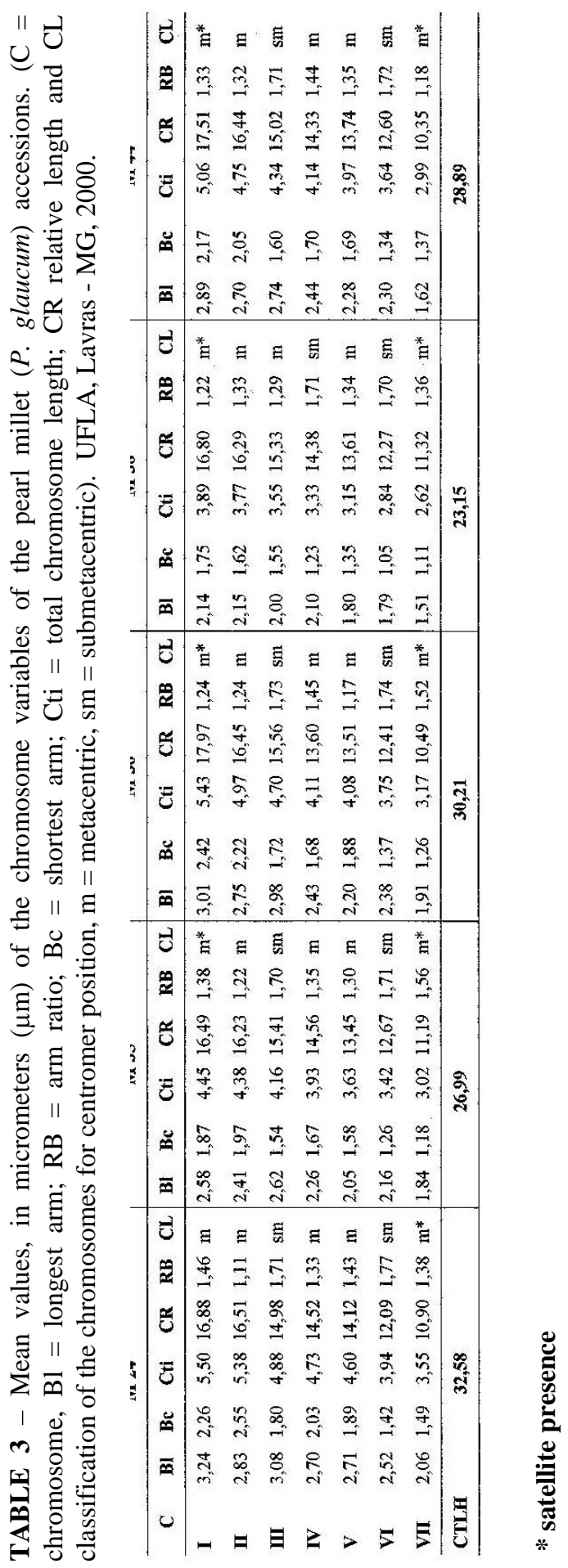


Elephant grass and pearl millet hybrids: Seven larger chromosomes probably derived from pearl millet and fourteen chromosomes from elephant grass were observed. This observation is in line with data presented by Burton (1942), Jahuar (1981) and Jahuar \& Hanna (1998).

The analysis of the relative length of the hybrids showed that the largest chromosome represented on average $7.9 \%$ of the haploid set length, reaching 2.7 times the size of the last, whose relative length represented on average $2.9 \%$ of the chromosome set (Table 4)and therefore was included in the $\mathbf{3 b}$ category of the Stebbins (1958) classification for asymmetrical karyotypes.

Metacentric and submetacentric chromosomes were observed on some metaphases in the five hybrids assessed. The $2^{\text {nd }}$ chromosome of the CNGL94-49-06 and CNPGL94-52-02 hybrids presented the VI and $\mathrm{X}$ chromosomes classified as submetacentric. The $2^{\text {nd }}$ chromosome of the CNPGL94-53-02 and CNPGL944-52-02 hybrids and the $10^{\text {th }}$ chromosome of the CNPGL94-53-02 accession were classified as submetacentric while the others were described as metacentric. Only metacentric chromosomes were recorded (Table 4) for the CNPGL94-60-01 hybrid.

Satellites were observed on the short arms of chromosomes I and VII in the metaphases analyzed in the CNPGL94-44-02 hybrid. The BAG 63 and M 36 accessions, parents of this hybrid, presented chromosomes with satellites. As it is reported in the literature that the seven largest chromosomes observed in the hybrid are derived from the pearl millet parent, it can be inferred that chromosomes I and VII are derived from the M 36 parent.

A satellite was detected on the short arm of chromosome III in the CMPGL94-49-06 hybrid. This hybrid is the result of the BAG 91 x M 38 cross and probably this chromosome is derived from pearl millet, although satellite presence was registered on chromosome I in this parent.

Satellites were observed on chromosomes I and IX in the CNPGL94-52-02 hybrid. The parents of this hybrid are the BAG 54 and M 44 accessions. Chromosome I is probably derived from the M44 parent, while chromosome IX, because it is the second among the fourteen smaller chromosomes of the hybrid complement, may correspond to chromosome I satellite of BAG 54.

Satellites were observed on chromosomes II and IX in the CNPGL94-53-03 hybrid. This hybrid results from the BAG $65 \times$ M 35 cross and satellites were observed on the first pair of chromosomes in both parents. Although there is no coincidence in the parents, chromosomes II and IX are derived from chromosome I of the pearl millet and elephant grass parents, respectively.

There was a satellite on chromosome $\mathrm{X}$ in the CNPGL94-60-01 hybrid. The parents of this accession are BAG 75 and M 24, in which satellites were also observed. As the satellite is on chromosome $\mathrm{X}$ and this is the third of the fourteen smaller chromosomes, it is suggested that this chromosome corresponds to chromosome $\mathrm{I}$ and is derived from the BAG 75 parent.

There are some considerations regarding the presence of secondary constriction. The pearl millet parent (AA genome) has satellites on chromosomes I and VII. In the elephant grass parent ( $\mathrm{AA}^{\prime} \mathrm{BB}$ ) genome), the satellites are found among the first chromosomes of the $\mathrm{A}^{\prime}$ genome and the last of the $\mathrm{B}$ genome. The hybrids presented only two chromosomes with secondary constriction, one corresponding to the largest pearl millet chromosome and one, of intermediate size, that might correspond to the smaller pearl millet chromosome or to one of the largest elephant grass chromosomes. therefore from $A^{\prime}$ genome. Thus there is a relationship of dominance of the $\mathrm{A}$ and $\mathrm{A}^{\prime}$ genomes over $\mathrm{B}$ genome in which the nucleolus organizer region was suppressed in the hybrid complement.

The chromosome complements of the hybrids and their parents were compared statistically. The Scott-Knott test (Table 5) showed the formation of three clusters based on total chromosome complement length: the first consisted of including the elephant grass and pearl millet accessions, the second consisted of the hybrids that presented the shortest chromosome complement length and the third group that consisted of the hybrids with longer length. 


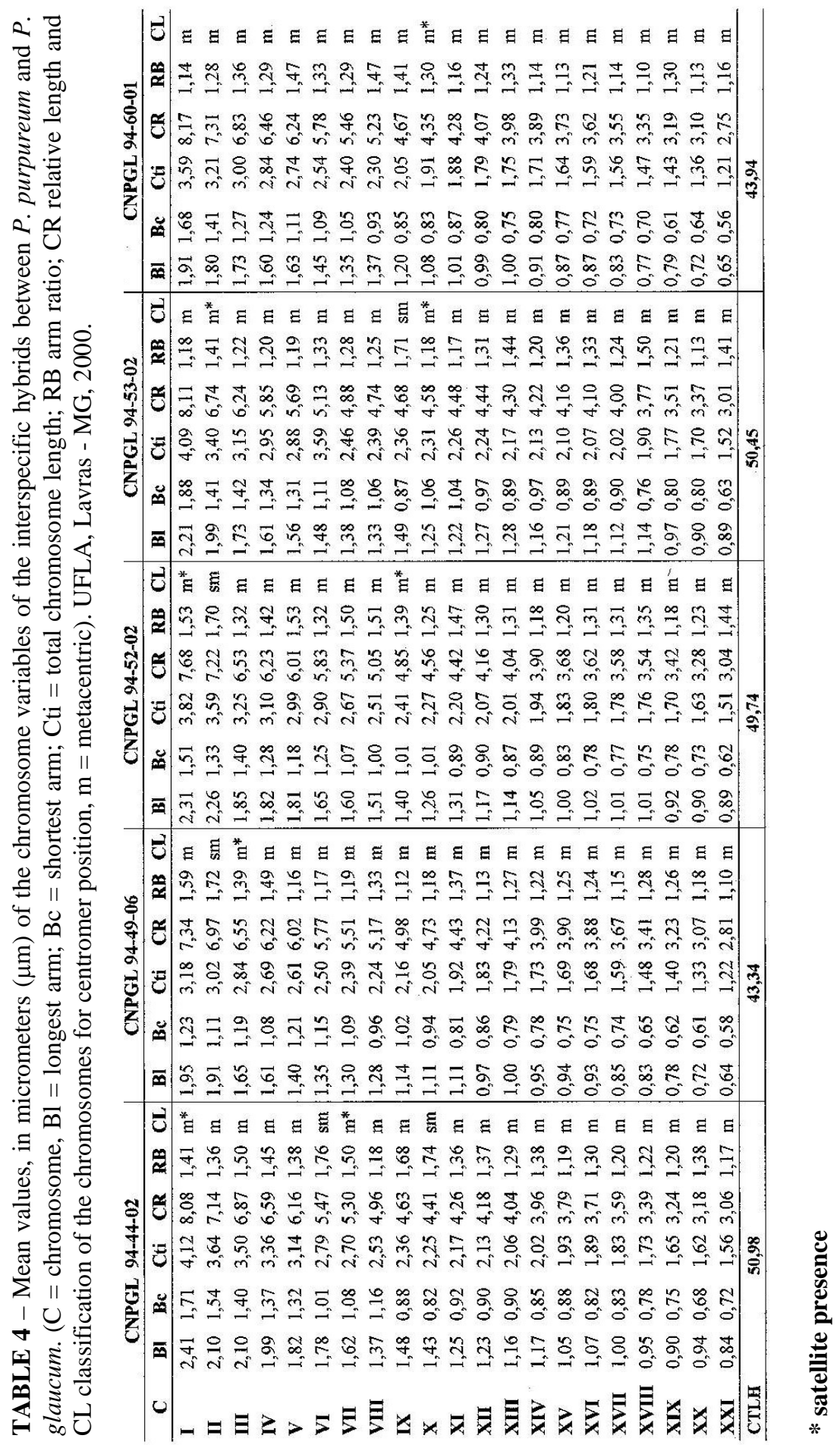

Ciênc. agrotec., Lavras. V.27, n.1, p.26-35, jan./fev., 2003 
TABLE 5 - Total complement length (CTLH) expressed in micrometers (um) for five $P$. purpureum and $P$. glaucum accessions and their hybrids. UFLA, Lavras, MG 2000.

\begin{tabular}{clllll}
\hline \multicolumn{2}{c}{$\boldsymbol{P}$ purpureum } & \multicolumn{2}{c}{ P. glaucum } & \multicolumn{2}{c}{ Híbridos interespecíficos } \\
\hline BAG 63 & $31,02 \mathrm{a}$ & M36 & $30,21 \mathrm{a}$ & F94-44-02 & $50,98 \mathrm{c}$ \\
BAG 91 & 27,88 a & M38 & $23,15 \mathrm{a}$ & F94-49-06 & $43,34 \mathrm{~b}$ \\
BAG 54 & $27,20 \mathrm{a}$ & M44 & $28,89 \mathrm{a}$ & F94-52-02 & $49,74 \mathrm{c}$ \\
BAG 65 & $27,65 \mathrm{a}$ & M35 & $26,99 \mathrm{a}$ & F94-53-02 & $50,45 \mathrm{c}$ \\
BAG 75 & $26,74 \mathrm{a}$ & M24 & $32,58 \mathrm{a}$ & F94-60-01 & $43,94 \mathrm{~b}$ \\
\hline
\end{tabular}

Means followed by the same letter, for each genotypic materials, for each genetic material, belong to the same group by the Scott Knott test $(0<0.05)$.

Significant difference was expected between the elephant grass and pearl millet CTLH because these species present different ploidy, chromosome number, botanical and agronomic traits. Furthermore, according to Panutlu \& Rao (1982), chromosomes 1 to 5 in both, and chromosomes 6 and 7 in pearl millet and 8 and 14 in elephant grass, paired in the meiosis of the hybrid but the seven chromosomes of the B genome of the elephant grass were not paired. The presence of a further genome in elephant grass would lead, therefore, to a larger genome. The inclusion of the pearl millet and elephant grass accessions in the same group may be explained by the expressive difference when the length of each chromosome is compared amongst the accessions of these species (Tables 2 and 3). The mean length of chromosomes 1 to 7 of the pearl millet accessions is $28.36 \mu \mathrm{m}$ while that of chromosomes 1 to 5 and 5 and 14 of elephant grass is $15.51 \mu \mathrm{m}$. Therefore, these two species diverge both by the presence of a genome in elephant grass (Jahuar, 1981) and by the occurrence of deficiencies in the elephant grass $\mathrm{A}^{\prime}$ genome. Furthermore, when the morphology of these homologous chromosomes is compared, it was ascertained that pericentric deficiencies or even inversions altered the morphology of some chromosomes since these are metacentric in elephant grass and the pearl millet chromosomes 3 and 6 are submetacentric.

The hybrids were grouped in two different categories and different from the parents that can also be explained by the occurrence of chromosome rearrangements.

\section{CONCLUSIONS}

The somatic number of chromosomes was confirmed for the five pearl millet and elephant grass accessions as being 14 and 28, respectively, for each taxa.

The hybrid nature of the five accessions resulting from the $P$. purpureum and $P$. glaucum cross was confirmed by the presence of 21 chromosomes in their mitotic metaphases.

The karyotypes of the P. glaucum accessions are symmetrical so they could be placed in the 1a category of the Stebbins (1958) classification while for the hybrids, the karyotypes were classified as asymmetrical and included in the $\mathbf{2 b}$ category. Two P. purpureum accessions (BAGs 63 and 75) showed symmetrical karyotypes and three showed asymmetrical karyotypes (BAGs 54, 65 and 91).

In the interspecific hybrids between $P$. purpueum and $P$. glaucum, the origin of some parental chromosomes could be inferred based on the mean of the chromosome total length, satellite presence and chromosome classification by centromer position.

\section{ACKNOWLEDGEMENTS}

The authors thank FAPEMIG for financial support and CAPES for the scholarship to the first author.

\section{REFERENCES}

AVDULOV, N. P. Karyosystematicshe untersuchung der familie graamineen. Bulletin Applied Botany and Plant Breeding, Leningrad, v. 4, p. 1-428, 1931. Supplement. 
BURTON, G. W. A cytological study of some species in the Tribe Paniceae. American Journal of Botany, New York, v. 29, p. 355-361, 1942.

BURTON, G. W.; POWELL, J. B. Pearl millet breeding and cytogenetics. Advances in Agronomy, New York, v. 20, p. 49-89, 1968.

DIZ, D. A. Breeding procedures and seed production management in pearl millet $x$ elephantgrass hexaploids hybrids. 1994. 118 p. These (Doctor) University of Florida, Florida.

GONZALEZ, B.; HANNA, W. W. Morphological and fertility responses in isogenic triploid and hexaploid pearl millet x napiergrass hybrids. Journal Heredity, New York, v. 75, n. 4, p. 317-318, 1984.

JAHUAR, P. P.; HANNA, W. W. Cytogenetics and genetics of pearl millet. Advances in Agronomy, New York, v. 64, p. 1-26, 1998.

JAHUAR, P. P. Cytogenetics and breeding of pearl millet and related species. New York: Alan R. Liss, 1981.

LEVAN, A.; FREDGA, K.; SOUBERG, A. A. Nomenclature for centromeric position on chromosomes. Hereditas, Lund, v. 52, p. 201-220, 1964.

MANARA, N. T. F. Citogenética de variedades de capim elefante (Pennisetum purpureum Schum.). 1973. 63 p. Dissertação (Mestrado em Genética) - Escola Superior de Agricultura "Luiz Queiroz", Piracicaba.
PANTULU, J. V. A case of chromosomal interchange in pearl millet. Current Science, Calcutta, v. 27, p. 497-498, 1958.

PANTULU, J. V.; RAO, K. Cytogenetics of pearl millet. Theoretical Appllied and Genetics, Berlin, v. 61, p. 1-17, 1982.

PANTULU, J. V.; VENKATESWARLU, J. Morphology of the pachytene chromosomes of Pennisetum purpureum Schum. Genetica, Grauenhage, v. 39, p. 4144, 1968.

SCHANK, S. C.; CHYNOWETH, D. P. Napier grass genotypes as biomassa and (or) forage. Tropical Agriculture, Trinidad, v. 60, n. 1, p. 83-87, Jan. 1993.

SCOTT, A. J.; KNOTT, M. A cluster analysis method for grouping measn in the analysis of variance. Biometrics, Releigh, v. 30, p. 507-512, 1974.

STEBBINS, G. L. Longevity, habitat, e release of genetic variability in the higher plants. Cold Spring Harbor Symposia Quantitative Biology, New York, v. 23, p. 365-378, 1958.

TECHIO, V. H.; DAVIDE, L. C.; PEREIRA, A. V.; BEARZOTI, E. Cytotaxonomy of some species and of interespecific hydrids of Pennisetum (Poaceae, Poales). Genetics and Molecular Biology. V. 25, n. 2, p. 203-209. June. 2002. 